\title{
Editorial
}

\section{Sobre verdades e mentiras nas publicações cientificas}

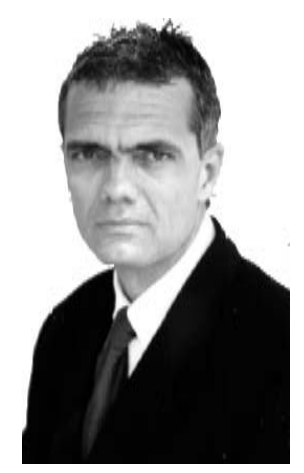

Marco Antonio Guimarães da Silva,Med.Dr.Sci. marco@atlanticaedu.com.br

Uma das mais coerentes definições de método que conheço, dada por Descartes, nos diz que "O método é a arte de se organizar uma série de diversos pensamentos, seja para descobrir algo que se ignora seja para levar a alguém alguma coisa que já se conhece".

Não cabe ao criador do racionalismo cartesiano a primazia de ser o único na sistematização metodológica, mas ele consegue sintetizar magistralmente, com poder de concisão jamais visto, a dinâmica da construção e do ciclo de continuidade da pesquisa cientifica.

Sabemos, todos os que trabalhamos com a investigação cientifica, que o apoio oferecido pelos trabalhos daqueles que nos precederam e que se encontram publicados nos periódicos são imprescindíveis e constituem um dos pilares da construção cientifica.

Tenho, nos julgamentos que faço como examinador de teses de Doutorado ou de dissertações de mestrado, procurado utilizar ao máximo as idéias contidas na definição descartiana. Afinal, o doutorando ao fazer a defesa de sua tese, deve com o trabalho escrito e com a defesa oral, demonstrar que soube levantar a literatura pertinente e que foi capaz de, baseando-se nestas consultas, realizar, sem vieses, o seu projeto de pesquisa. Finalmente, esse doutorando, deve contextualizar a construção de sua tese no documento escrito, de modo a se adequar à formatação acadêmica exigida.

Poderíamos ser muito felizes e executar o nosso trabalho inicial de seguir, sem preocupação, as pistas deixadas por outros investigadores, caso não existissem duas situações, talvez mais presentes do que imaginemos, no nosso cotidiano laboral, e que são: os equívocos cometidos por aqueles que pensam que sabem fazer investigação cientifica; e a adulteração de dados, em sua maioria, cometida pelos que sabem fazer a pesquisa.

Já tive oportunidade de, em outros editoriais, falar sobre os que, por desconhecerem metodologia da pesquisa, nos levam, como pesquisadores, a ter muitíssima cautela quanto às interpretações dos resultados e conclusões contidos nas pesquisas que fazem. O problema dessas pesquisas equivocadas e publicadas não se circunscreve à regionalizações e alcança indiscriminadamente um parque editorial mundial que reúne os mais variados periódicos, incluindo-se aí, também, os de grande impacto. Eu diria que esses pesquisadores estariam transmitindo uma verdade relativamente absoluta, já que a possibilidade de estejam errados existe.

Por outro lado, de vez em quando, a imprensa noticia fraudes em investigações cientificas que acabam por tornarse, à dependência da importância da pesquisa, em grandes escândalos.

O último desses escândalos de que se tem notícia recente foi a fraude cometida por um investigador, praticamente um herói em seu pais, que manipulou os dados de suas pesquisas com o DNA e contou para a comunidade cientifica uma grande mentira. A Science, revista escolhida pelo pesquisador para desova de sua mentira, se retratou e tomou a providência de exigir dos pesquisadores, a partir de agora, os detalhes de suas contribuições ao estudo e, ainda, que os autores assinem declaração de veracidade das conclusões encontradas. A questão de solicitar do investigador uma declaração assinada da veracidade de seus procedimentos, sob meu ponto de vista, não resolve. Não soluciona o problema levantado, simplesmente porque o pesquisador mentiroso acaba por convencer-se de que diz a mais pura das verdades, passando a acreditar em sua mentira; algumas vezes, não tendo sequer consciência da falsa situação em que vive. Aqui, a mentira, acaba sendo absolutamente relativa e pode, em alguns casos, passar por verdade.

Só nos resta, como editores e leitores, esperar que a decência triunfe ao menos no campo científico, e que as verdades contadas pelos nossos pares sejam verdades "absolutamente" absolutas. 